\title{
Current initiatives, barriers, and opportunities for networked learning in Latin America
}

\author{
Enilda Romero-Hall ${ }^{1}$ D
}

Accepted: 29 January 2021 / Published online: 8 February 2021

(c) Association for Educational Communications and Technology 2021

\begin{abstract}
This paper explores and describes the current initiatives, barriers, and opportunities for formal, non-formal, and informal networked learning experiences using social media in Latin America. It focuses on networked learning initiatives such as the use of institutional social media accounts, educational hashtags, social media in the classroom, educational channels via video hosting platforms, and government established networked learning programs for connected classrooms. The same multiplicity, diversity, and heterogenicity that represent the culture, languages, and socio-economic status of the people of Latin America also characterize the vast mixture of networked learning initiatives across the region. Potential barriers (i.e., the digital divide, Internet filtering policies, lack of research) and opportunities for implementation (i.e., networked learning educational reforms, mobile learning technology, and social media ethical considerations) are explored. The paper concludes with recommendations that policymakers and education leaders in Latin America should keep in mind to engage in fruitful networked learning initiatives.
\end{abstract}

Keywords Connected learning $\cdot$ Networked learning $\cdot$ Social media $\cdot$ Mobile learning · Latin America $\cdot$ Information and communications technology

\section{Introduction}

People around the world spend a significant amount of time using social media (Social Media Fact Sheet 2019). Social media is defined as a group of Internet-based applications for the creation and exchange of user generated content (Constantinides and Zinck Stagno 2011). These applications take on many different forms, including blogs, wikis, and social networking sites. Users log into their social media accounts to keep up with their friends, family, and acquaintances, as well as to update others about their daily life. Social media has also infiltrated the educational arena (Gao et al. 2012). There are many research efforts focused on the use of social media in formal teaching and learning (Manca and Ranieri 2017; Gao et al. 2012).

Enilda Romero-Hall eromerohall@ut.edu

1 University of Tampa, 401 W. Kennedy Blvd., Tampa, FL 33604, USA 
The results are mixed on whether young individuals favor using social media in their formal learning experiences (Greenhow and Lewin 2016). Also, researchers have warned against the use of social media for learning due to potential adverse effects and risks such as privacy, bullying, addiction, misinformation and others (Eckberg et al. 2018; Aydin 2012; Annisette and Lafreniere 2017; Whaite et al. 2018). However, social media has the potential to engage users through collaboration, allow connection with educational content, and help blur the line between formal, non-formal, and informal learning (Chen and Bryer 2012; Greenhow and Lewin 2016). A key aspect that could be nurtured within social media communities is networked learning.

Networked learning using social media has been studied by researchers wishing to understand how and when learners can benefit from its implementation in education (Trust and Prestridge 2021; Greenhalgh and Koehler 2017; Alzain 2019; Kearney and Maher 2019; Kennedy 2018). However, the literature shows a lack of investigations on whether these types of networked learning experiences using social media (a) are currently occurring, (b) have been considered for implementation, and (c) can enhance learning within the Latin America regional context.

In 2019, the International Summit on Information and Communications Technology (ICT) in Education met to discuss topics related to the theme: "Learners and Learning Contexts: New Alignments in the Digital Age." It is within the context of the summit and the thematic working groups (TWG) 7: "Connected learning: Online human interaction and interaction with digital resources," that this paper explores and describes the current initiatives, barriers, and opportunities for formal, non-formal, and informal networked learning experiences using social media within the context of Latin America.

\section{Framework for networked learning using social media}

The use of social media in education is increasing rapidly (Manca and Ranieri 2017). Researchers have explored social media in formal, non-formal, and informal learning environments (Gao et al. 2012). Formal learning refers to intentional education in which learning occurs through a program of instruction in a structured manner leading to a recognized qualification or certificate (OECD 2005). Non-formal learning refers to learning through a program; this may not necessarily lead to a certificate or even a formal evaluation (OECD 2005). Informal learning denotes education that results from daily work-related, family, or leisure undertakings; it is not organized, has no set objectives, and is not intentionally done as a learning activity (Werquin 2007).

Most of the research efforts related to social media in formal, non-formal, and informal learning have occurred in a higher education setting. However, social media has also been integrated and investigated in secondary education with teenage populations (Dennen et al. 2020). Today, social media in teaching and learning is used to expand formal learning environments across geographically-dispersed educators (Carpenter et al. 2020), serve as an outlet of professional development for instructors (Carpenter and Krutka 2014; Luo et al. 2020) and learners (Romero-Hall 2017b; Rosenberg et al. 2016), facilitate networked scholarship (Veletsianos 2016), engage in informal learning opportunities (Greenhalgh and Koehler 2017), and share information and resources from institutions (Kimmons et al. 2016; Veletsianos et al. 2017) and educational programs (Romero-Hall et al. 2018) to members of their communities and the public. 
The success of the integration of social media into teaching and learning in secondary and higher education varies tremendously based on the context. For example, there have been positive reports on the use of social media by graduate students for professional development (Romero-Hall 2017a). However, for undergraduate students, their class standing can make a difference in their participation and motivational factors (Romero-Hall et al. 2020). Krutka and Damico (2020) also reported a lack of interest by pre- and inservice teachers across two universities when assigned to use social media as professional learning networks. The results indicated that learners tweeted more around deadlines and quit using their social media accounts once the class ended (Krutka and Damico 2020).

In addition to context specific implementations for teaching and learning, researchers also believe that there is a need to problematize social media use and its numerous implications. This would require increasing learners' awareness of privacy and terms of service, the use of algorithms, cyberbullying and harassment, and information accuracy and democracy (Krutka et al. 2019). As stated by Krutka, Heath, and Mason (2020), instructors and learners must take on a technoskeptical approach in which the downsides, constraints, and cultural characteristics of technologies, such as social media, are scrutinized in both personal and educational contexts.

Overall, it is worth it for instructors to consider adequate opportunities for social media in education, while avoiding techno-deterministic setups and considering technoskeptical tactics. With a conscious effort, social media offers opportunities to cultivate, encourage, and foster networked learning in formal, non-formal, and informal learning experiences (Rehm and Notten 2016; Greenhalgh and Koehler 2017; Carpenter and Krutka 2014).

The Networked Learning Editorial Collective (2020) has re-defined networked learning and stated that it "involves processes of collaborative, co-operative and collective inquiry, knowledge-creation and knowledgeable action, underpinned by trusting relationships, motivated by a sense of shared challenge and enabled by convivial technologies" (p. 9). Networked learning incorporates seeking knowledge, learning through time, and learning as a social and active process (Davis 2013). Learners work to gather, filter, and organize content to make meaning while also sharing content and their viewpoints through social web applications (Kennedy 2018).

Learning through connected networks can blur the line between formal, non-formal, and informal learning. According to Kennedy (2018), "the transfer of knowledge and skills to the workplace and lifelong learning are some of the potential outcomes of integrating networked learning into higher education." The wide acceptance of mobile devices has helped social media applications and networked learning gain popularity by making content and communication accessible at all times (Juric et al. 2018). Similarly, networked learning is grounded on the openness of our connections to other learners, instructors, learning communities, and learning resources (Carvalho 2018).

\section{Educational reforms in Latin America}

Latin America and the countries that are part of it have been defined differently by many. In this paper, Latin America refers to Mexico, Central America, South America, and islands in the Caribbean whose inhabitants speak a Romance language (see Fig. 1). Most think of Latin America as a Spanish speaking section of world. Yet, Portuguese is spoken in Brazil, Dutch is spoken in Suriname, English is spoken in Guyana and the Falkland Islands, and French is spoken in French Guiana. Additionally, there are various 


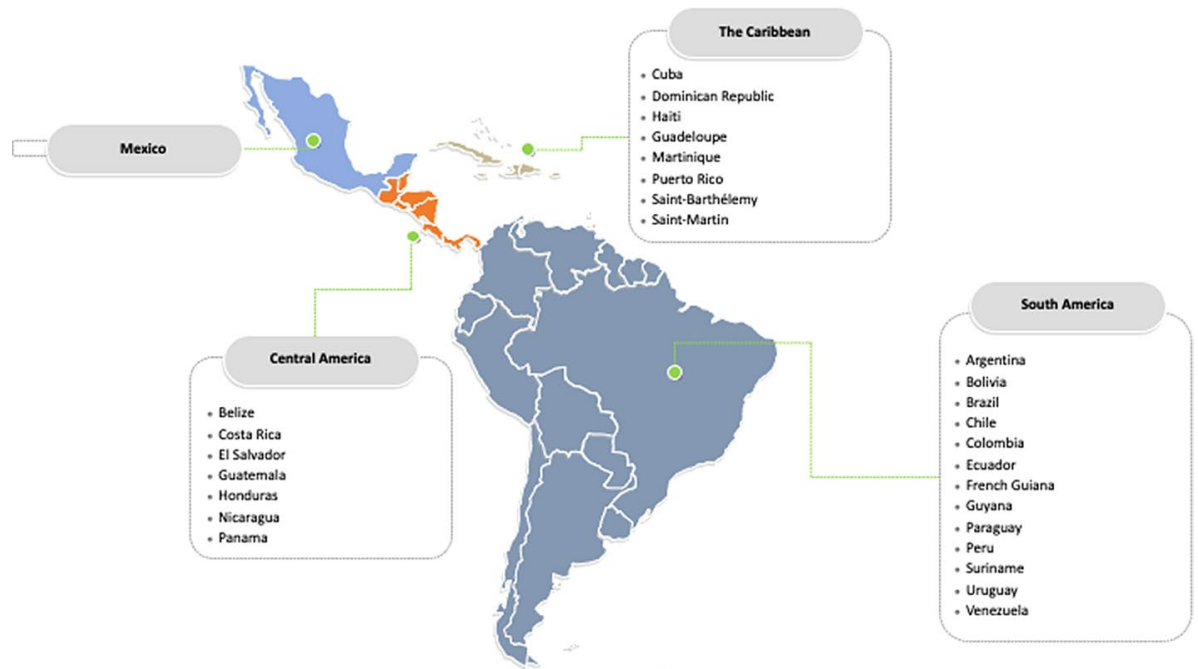

Fig. 1 Latin American countries

indigenous language spoken across Latin America such as Quechua, Guarani, Aymara, Nahuatl, Caribe, Chibcha, Arawak, Mapudungun, and many others. Last, various migrations to Latin America from people in Asia and Europe have let to pockets of Japanese, Italian, and German spoken in many communities within the region.

Historically, Latin America has experienced a high level of economic and social inequality (Lugo and Schurmann 2012). This lack of economic equality has had a tremendous impact on education at all levels (i.e., primary, secondary, and higher education). The 1980s is considered the "lost decade" in Latin America due to the harsh period of acute economic recession, inadequate transitions to democratic rule, and a lack of economic structural programs (Bernasconi and Celis 2017). Yet, the world continued to move through an era of globalization and knowledge societies. Over the last two decades, Latin American countries have undergone several attempts to introduce changes to their national education systems (Bernasconi and Celis 2017). These attempts were primarily employed in higher education. The goal has been to implement public policies to transform totally or partially the structure or organization of higher education systems in governance, funding, and results (Bernasconi and Celis 2017). Of course, there are exceptions to this statement. Trends of change have not been homogenous throughout the region.

According to Amadio (2009), an exploratory analysis of national reports determined that the main education challenge in the region was the gap between the stated vision and the actual practices of inclusive education. Of course, the importance of having alignment between education visions, policy, and practice is well established (Butler et al. 2018). Yet, the reality was that there was a need to ensure that policies and strategies translated into concrete actions aimed at changing institutional practice and pedagogical approaches (Amadio 2009). Despite these challenges, the first wave of reforms involved evaluation and accreditation systems, the creation of new public institutions of higher education, support for research and graduate programs, and the introduction of new strategies for allocating public funding. 
However, there were still aggravating factors, such as programs and policies that did not consider specific needs of each population segment: indigenous people, afroLatinx, women, learners with disabilities, and others (Gadotti 2011). Recently, policies have focused on the maintenance and consolidation of the initiatives previously mentioned; however, there has been an emphasis on access and equity (Bernasconi and Celis 2017). One example of this is the affirmative action policies taken in Brazil to address structural barriers keeping students of color from attending the public higher education system (Arnett 2015).

\section{The infrastructure of ICT integration in Latin American education}

ICT plays a significant role in Latin America in the context of access and equity. ICT has been integrated into the region's educational reform agendas to improve the quality and increase access to education for all students. In the first stage, ICT programs aimed at providing infrastructure, mostly through the installation of computer labs in schools and universities (Jara et al. 2012). This initial stage also included ICT training to enhance the skills of teachers and students who normally do not have access to computers outside of school. The second stage of ICT integration in Latin America aimed at providing connectivity. The emergence of the Internet in the mid-1990s expanded initiatives and focused on offering digital content that could support schoolwork. Then in the 2000s, the third stage of ICT initiatives led to web-based education portals focused on relevant national curricula (Lugo and Schurmann 2012).

One challenge that remained was that despite best efforts to provide access, instructors were often limited to using computers in computer labs rather than individual classrooms (Lugo and Schurmann 2012). This translated into instructors with ICT skills but unable to put them into innovative practices in the classroom. As an attempt to mitigate the issue of access to resources, many countries in the region adopted a 1:1 program, which provided each student and teacher with a laptop or netbook to use at school and sometimes at home (Jara et al. 2012). The aim was to reduce the digital divide.

The digital divide in Latin America is more prominent in low income urban and rural populations as well as in indigenous communities. Distribution of resources often lack equity. Therefore, institutions in low-income urban sectors or rural areas are often left to survive with very few resources (Ontiveros et al. 2013). As a potential solution to mitigate the effects of the digital divide, education stakeholders began exploring mobile learning as a possible strategy for addressing some of the region's most pressing educational needs (Lugo and Schurmann 2012). Access to and the use of mobile phones is increasing in Latin America. Mobile devices and data services are fairly easy to set up and cheaper than an at-home computer with high-speed Internet access.

At the policy level, mobile learning is still in its infancy. Still, the proliferation of mobile technologies in Latin America has the potential to reach the region's marginalized population by increasing access to educational materials and programs (Kim et al. 2008). Through mobile learning policies and initiatives, networked learning in formal, non-formal, and informal settings using social media can occur in the region's education systems. 


\section{Networked learning initiatives in Latin America}

As a region Latin America has the fastest growth in Internet users and dominates the global rankings of online engagement (Gainous et al. 2016). An overwhelming majority of Internet users in Latin America engage by using social media sites (Gainous et al. 2016). This growth in internet usage, specifically social media, raises important implications for networked learning opportunities. Networked learning using social media has provided mechanisms through which instructors and learners can mobilize knowledge; create affinity spaces to join; coordinate formal and non-formal learning experiences; and engage with like-minded people (Trust and Prestridge 2021; Greenhalgh and Koehler 2017; Carpenter and Krutka 2014). Given these regional trends, instructors could potentially design formal, non-formal, and informal networked learning opportunities that cater to the needs of learners.

Social media is increasingly used as a means of communication and knowledge sharing in Latin America. For example, Duque and del Moral Pérez (2013) analyzed 263 institutional Twitter accounts of Latin American universities. They found that Twitter was mostly used by institutions in Chile, Colombia, Brazil, Mexico, the Dominican Republic, and Venezuela. However, other countries across the region used it fairly frequently (Argentina, Ecuador, El Salvador, and Peru). The universities with the highest number of followers tweeted the most, shared content with followers using hashtags, followed users to find out about their topics and publications, and consequently generate a multidimensional communication flow (Duque and del Moral Pérez 2013).

The use of Twitter chats using hashtags is another example of networked learning currently occurring in Latin America. According to Staudt Willet (2019), on Twitter affinity spaces rely on hashtags as the primary organizing feature. Twitter education hashtags have been organized around numerous topics and geographical locations (Staudt Willet 2019). One example is \#LatamEd. The hashtag \#LatamEd is used to connect educators, education foundations and non-profits, education researchers, and institutions of higher education to discuss topics such as innovation in elementary education, educational leadership, and sustainable innovation programs in education, amongst others. The hashtag is also used to share resources, information about programs, scholarship, academic articles, and others. This is one of the main Twitter hashtags used to discuss topics related to education in the Latin American region; however, many others are used, such as \#educarchile and \#fomentolectura.

Another networked learning initiative occurring in Latin America is the use of educational channels in online video hosting platforms, such as YouTube. These educational channels disseminate virtual classes related to different topics and provide access via mobile phone. An example of this type of educational channel is Ayudinga, established by a foundation in Panama that provides courses related to math, biology, physics, and chemistry. The courses are delivered via YouTube live and archived for later viewing. The content created by Ayudinga is also disseminated in other digital platforms such as Instagram, in which they are followed and connected with a network of thousands of prospective learners.

In more recent times, the emergency response to the COVID-19 pandemic, in which many schools had to switch from face-to-face instruction to remote instruction (synchronous or asynchronous), has led to the use of other social media in teaching and learning. In several countries in Latin America, the emergency response in education encourages some institutions to consider the use of live virtual classes using Instagram 
Live and Facebook (Cobo et al. 2020). These social networking tools are available as both a browser and mobile phone application format.

Several organizations are implementing additional community and government programs to support networked learning in the education systems in different countries in Latin America. In Argentina, the Ministry of Education created a program for learners 9-13 years old called "Aprender Conectados" (Benítez Larghi 2020). This program integrates educational and technological innovation and increases digital literacy through learning communities (Benítez Larghi 2020). Through networked learning, the students work together to increase their knowledge of Scratch, web programming (HTML and CSS), and Python. In Chile, the Innovation Center sponsored by the Ministry of Education has created an initiative called "Aulas Conectedas." The objective of this initiative is to personalize learning through the use of educational technology and online resources (Centro de Inovacion 2019). The aim is to establish projects that allow instructors in their classrooms to access other networks to support instruction at all educational levels (Centro de Inovacion 2019).

Learners in Latin America are open to networked learning initiatives using social media in teaching and learning. An investigation conducted by Cabero and Marin (2013) found that students in Latin American countries have extensive experience using the Internet for educational work, which enables a certain level of "virtual mobility" for learning. In their research, Cabero and Marin (2013) determined that learners perceived themselves as having good social media skills and experience using the Internet for learning. Students preferred Facebook over Twitter and LinkedIn (Cabero and Marin 2013). Very similar results were found by Gonzalez and Muñoz (2016). They investigated the level of acceptance and participation in social media by students, instructors, and administrators in an institution of higher education in Panama. The results also provided strong support for the use of Facebook, as well as Twitter and LinkedIn, in education. More significantly, many of the participants surveyed confirmed that they used social media to support their academic work as learners or instructors (Gonzalez and Muñoz 2016). By contrast, an investigation by Rodriguez and Restrepo (2015) found that higher education students in Colombia did not use Twitter very often or perceive it as a beneficial educational tool for learning. However, higher education students agreed that Twitter was a good source of resources and information. Therefore, Rodriguez and Restrepo (2015) emphasized the importance of promoting strategies to help instructors engage creatively with networked learning technologies that can potentially enhance learning experiences by sharing information and increasing collaboration.

\section{Factors influencing networked learning in Latin America}

\section{Barriers}

Several barriers should be considered before implementation or consideration of networked learning initiatives in Latin America. Some of these barriers are the digital divide, the Internet filtering policies of governments, and lack of assessment and evidence to support these initiatives (see Fig. 2). 


\section{Barriers}

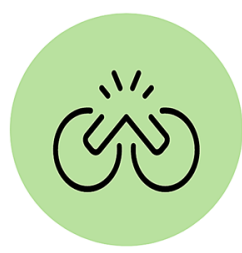

Digital Divide

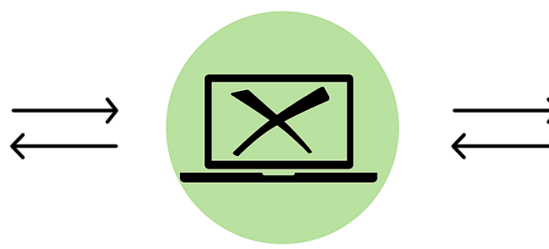

Internet Filtering Policies

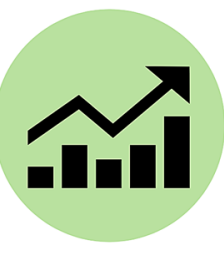

Lack of Research

\section{Opportunities}

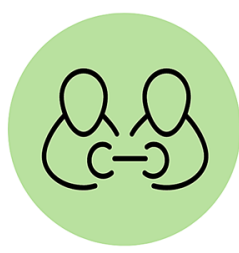

Educational Reforms

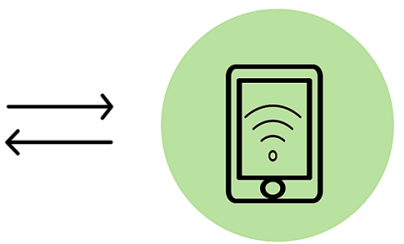

M-Learning Technology

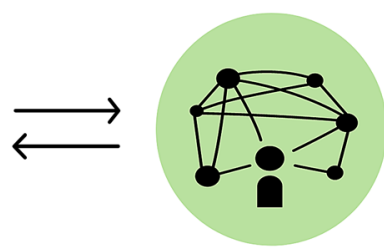

Social Media Ethics

Fig. 2 Barriers and opportunities to consider before further implementation of networked learning in Latin America

\section{Digital divide}

The digital divide is "really a socioeconomic, cultural, and power divide that exists at both local and global levels" (Bishop et al. 2001). It impacts both social justice and technical communication. We often equate the digital divide with just lack of access to the Internet; however, there are many other factors such as affordability, usage, social resources and skills, infrastructure, and literacy skills (Ding 2020).

Increased networked learning, via social media, using mobile phones presents digital divide challenges related to mobile bandwidth affordability. Although, the cost of mobile bandwidth has diminished in Latin America, it can still be a significant expense for lowincome families. A report from 2016 revealed that mobile devices represents 17 percent of the income for the poorest 40 percent of Latin Americans but only two percent for the wealthiest (Sucre and Manning 2016). In addition to the cost of mobile bandwidth affordability, it is crucial to address the cost of the devices. Mobile phones are a more accessible and low-cost substitute for computers. However, mobile phones that can be used to access the Internet and run social media applications are often a luxury for underpaid workers.

The digital divide also is visible in terms of lack of digital literacy. To fully integrate networked learning using social media applications, instructors and learners need to fully understand how to take advantage of the Internet and mobile technology. There are still faculty and students who are hesitant to use mobile learning technologies, such as social media, or do not know how to integrate it into their academic work (Fainholc 2016; Rodriguez and Restrepo 2015). 


\section{Internet filtering policies}

The Internet represents a medium in which individual-level use can shift attitudes. Users could be controlled or influenced by filtering schemes. However, the most heavyhanded Internet controls are often set by the state (Deibert et al. 2008). These regulations can require filtering of digital media challenges to the status quo; it aims to limit the Internet's utility for change. These regulations take different forms, such as limited access, filtering, firewalls, control of search engines, control, or block of certain websites or portals (Gainous et al. 2016). These regulations aim to limit the dissemination of information, creating a boundary on the Internet's alternative information sphere that, in turn, limits changes in attitudes (Gainous et al. 2016). In Latin America, there are countries in which state-authored regulations have been used to control access, limit what citizens can share, or encourage self-censorship (Gainous et al. 2016). Countries with internet filtering policies include Colombia, Mexico, and Venezuela. Given the history of political instability in the region, Internet filtering policies could be a barrier to networked learning in the future.

\section{Lack of research}

A review of the literature related to mobile learning initiatives, networked learning, and the use of social media in teaching and learning in Latin America reveals very little research, assessment, or evaluation on past or existing initiatives. The lack of follow-up indicates that there are limited results or evidence on whether past or current efforts are helping to improve learning outcomes (Sucre and Manning 2016). This could prevent further support from institutions, instructors, and students as well as funding entities. Unfortunately, current organizational structures do very little to promote research in digital humanities (Fainholc 2016).

Some have argued that it is vital to highlight the singularity of every country, given that each state has different social, political, and economic issues and policies (Fainholc 2016). With this in mind, it is even more critical to have adequate research, assessment, and evaluation of the outcomes of the different initiatives. There are various analyses related to interactions that are critical. We should aim to understand what is occurring as initiatives are implemented in interactions between: learners, learners and instructor(s), and learners and their networked learning environments (Ontiveros et al. 2013).

\section{Opportunities}

Networked learning brings several opportunities to the region. These opportunities enhance current initiatives and propel new advances for networked learning (see Fig. 2).

\section{Networked learning-educational reforms}

The role of education has shifted from being a fundamental factor with a major impact on economic development and modernization to a more critical role in promoting global values (Blasco and Krause Hansen 2006). As mentioned by Gebera (2010), educational reforms have aimed to educate citizens that are critical, constructive, and reflective to nurture a society in which information and knowledge prevail as the sources of influence 
and wellness. In Latin America, the evolution of ITC in higher education and educational reforms should continue to parallel the demands of globalization, technological development, and the need for new types of knowledge and skills (Gebera 2010). Future initiatives can focus on networked learning in higher education and other educational levels. Networked learning is an excellent opportunity to foster educated global citizens from an early age (Centro de Inovacion 2019; Benítez Larghi 2020).

\section{Mobile learning technology}

Countries in Latin America have aimed to focus on educational reforms that promote access and equity. With that in mind, some ITC initiatives have migrated to the use of technological resources that are more easily accessible to the general population. Mobile learning is an emerging technology that can be more available to all learners in Latin America. So far, there are several governmental and community organizations that focus on launching mobile learning programs (Jara et al. 2012). For example, the national alphabetization program in Colombia, the PSU movil program in Chile, the mobiles for supervisors in Argentina, the evaluation of learning through mobile phones in Paraguay, and the BridgeIT and Seeds of Empowerment program in various Latin American countries (Jara et al. 2012). While mobile learning technologies refer to mobile phone technology only, mobile learning may incorporate other mobile technologies, such as tablet computers, these devices are far more costly and have limited availability (Jara et al. 2012).

If designed and funded adequately, a move in the direction of mobile learning technology can serve to reach vulnerable populations to meet literacy and basic education needs (Kim et al. 2008; Valencia-Arias et al. 2018). Mobile learning technology can also aid in the administrative management of education systems in Latin America (Lugo and Schurmann 2012). Factors that enable this movement of mobile learning technologies include the high penetration rate of mobile phones and the level of familiarity that instructors, staff, and students have with mobile devices (Lugo and Schurmann 2012). Recent research has found that there is a strong support from instructors across Latin America for the use of mobile learning technologies (Ballesteros Ballesteros et al. 2020; Valencia-Arias et al. 2018). Additionally, one last enabling factor is that analysts continue to forecast an increase in mobile broadband services (Lugo and Schurmann 2012). So far, Alderete (2019) has reported that mobile broadband penetration growth in Latin American countries has increased on average from $8.27 \%$ in 2011 to $44 \%$ in 2015 .

\section{Social media ethical considerations}

The implementation of networked learning initiatives in Latin America provides the opportunity to teach about ethical practices for use and teaching of social media. Over the last few years, several social media platforms that are used in teaching and learning practices have been involved in (a) unethical use of user data, (b) surveillance of their users' activities, (c) inadequate monitoring for abuse by other users, (d) spreading misinformation and other disreputable behaviors (Krutka et al. 2019). Therefore, educators wishing to use social media as part of their networked learning initiatives must educate learners on issues that could arise when engaging in activities using these platforms. As stated by Krutka et al. (2019): "educators, particularly those of us encouraging students to log on to these platforms, should consider questions such as: how do social media companies make 
money? To what degree do profit motives compromise transparency, equity, health, safety and democracy?".

Another critical consideration is the opportunity to educate learners about "context collapse" (Dennen and Burner 2017) and the resulting tensions or conflicts (Veletsianos 2016) that could arise from using personal networks via social media for networked learning. According to Dennen and Burner (2017), "context collapse occurs when multiple social settings come together in the same online space." This often occurs when an individual has to manage using a social media platform as both a personal and professional space. This leads to tensions related to identity, in which an individual may have to behave differently in different social arenas online (Dennen and Burner 2017). Creating an understanding of context collapse prior to implementation of networked learning initiatives serves to prevent tensions and conflicts.

\section{Recommendations for policymakers and education leaders in Latin America}

After examining the current initiatives, barriers, and opportunities for networked learning using social media in Latin America, it is important to identify specific areas of prospects that can improve networked learning in this specific region and context (see Fig. 3). The following are a range of recommendations for policymakers and education leaders in Latin America:

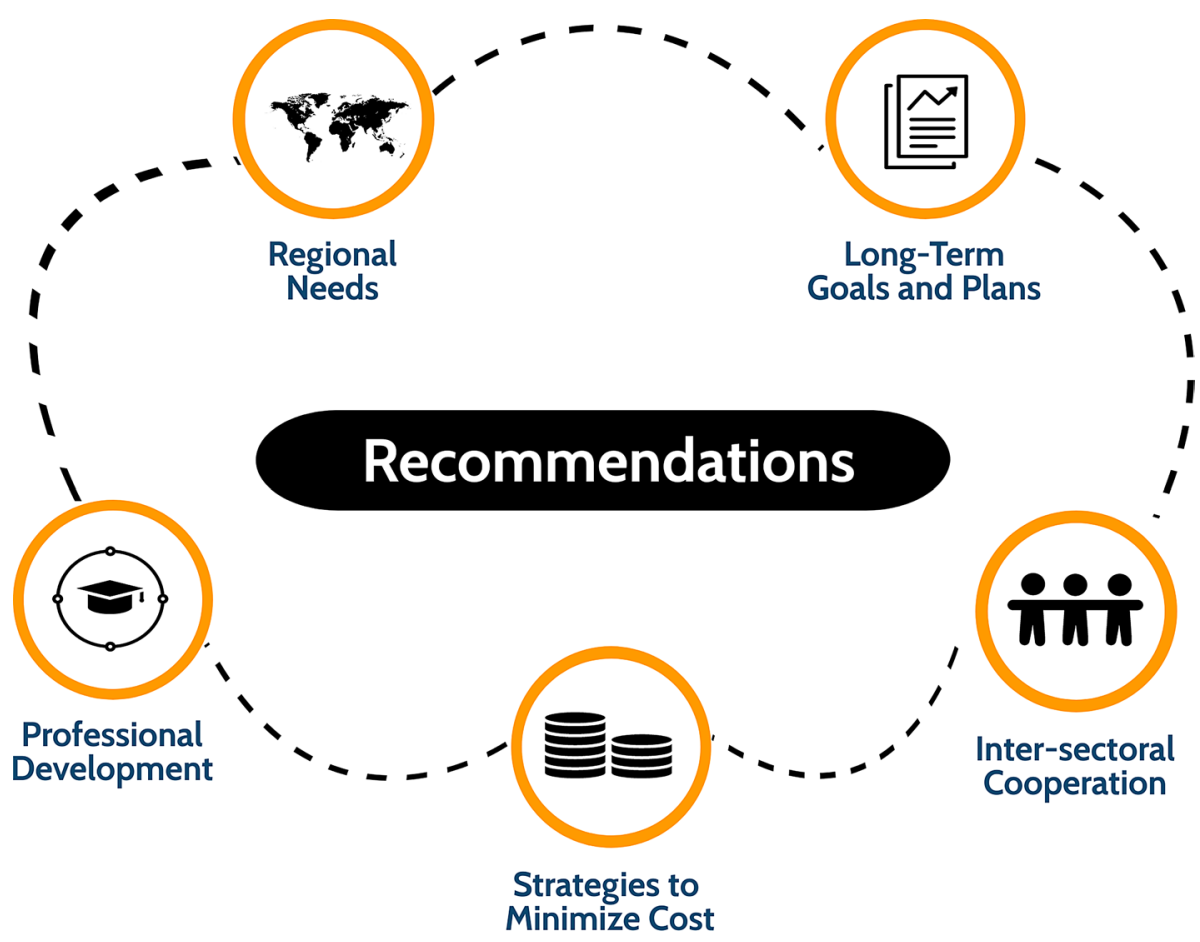

Fig. 3 Areas of prospects that can improve networked learning in Latin America 
- Regional needs Latin America is often referred to as a socio-cultural homogeneous unit. Yet, different countries in Latin America have dissimilar socio, political, cultural and educational needs (Fainholc 2016; Yuni et al. 2014). Some researchers have even stated that Latin America is an imaginary construct, given the multiplicity, diversity, and heterogenicity that runs and constitutes its current society and historical-political configuration (Rodríguez 2009; Yuni et al. 2014). Therefore, it is critical for Latin American policymakers and education leaders to research the needs of the individuals in each country, region, or specific setting. Considering and studying country-, region-, or setting-specific needs will allow those involved to set realistic initiatives that (a) adequately address the needs of the learners involved, (b) gain support from different stakeholders, and (c) move forward from a concept or idea to implementation

- Strategic long-term goals Depending on the type of networked learning initiative, formal or non-formal, it would be beneficial for policymaker and education leaders in Latin America to consider establishing long-term goals or plans for implementation. Within these goals and plans, policymakers and education leaders can determine anticipated technological issues, technical support, alignment with curricula, instructional support, roles of those involved, funding, maintenance of existing and new partnerships, and educational outcomes, among others (Jara et al. 2012). Of course, many of these factors should be considered for any ICT integration initiative, not just networked learning

- Intersectoral cooperation These types of coalitions between different types of organizations can allow networked learning projects to scale up from exploration to research and then on to implementation and maintenance (Jara et al. 2012). These intersectoral cooperation alliances can include academic institutions, government, non-governmental organizations, and private organizations. Some of the existing networked learning initiatives mentioned in this paper, such as a the "Aulas Conectadas" in Chile (Centro de Inovacion 2019) and the "Aprender Conectados" in Argentina (Benítez Larghi 2020), were the result of intersectoral cooperation alliances between government institutions working with academic and non-government institutions. In general, intersectoral cooperation alliances have aided in the implementation of collaborative efforts with a socio-educational focus (Mayayo et al. 2020). For example, the CaixaProinfacia "La Caixa" program is an intersectoral cooperation with a socio-education emphasis, which was developed with the intent to combat the social and educational exclusion of children in 18 different regions of Spain (Mayayo et al. 2020). Intersectoral cooperation alliances are critical for the implementation of networked learning initiatives that are sustainable over time

- Strategies to minimize costs The involvement of intersectoral cooperation amongst potential alliances can be a strategy to minimize costs. Current or future networked learning initiatives in Latin America could distribute the costs or resources amongst those involved in an intersectoral cooperation alliance. Alternative strategies could be to engage in an intersectoral cooperation alliance in which certain organizations help reduce implementation expenses while others aim to support maintenance expenses. Ideally, learners can access networked learning initiatives that (a) are affordable to maintain long-term by members of an intersectoral cooperation alliance and (b) do not represent an additional expense in their educational experiences

- Professional development As mentioned by several research efforts (Fainholc 2016; Rodriguez and Restrepo 2015; Twining et al. 2013), instructors often lack the basic knowledge of ICT integration at different educational levels. The topic of "instructor professional development focused on ICT integration" has been discussed widely by 
many organizations, including the EDUsummIT events in 2009 (Albion et al. 2011) and 2011 (Twining et al. 2013). Latin American policymakers and education leaders should aim to continue moving forward with educational reforms that address ICT integration knowledge and skills. Furthermore, professional development on ICT integration knowledge and skills should include networked learning application at both the macro and micro level. Issues related to effective professional development are not new but often not addressed or not addressed effectively (Twining et al. 2013).

\section{Conclusion}

This paper aims to explore and describe the current initiatives, barriers, and opportunities for networked learning experiences using social media within the context of Latin America. This topic is motivated by the TWG7 "Connected learning: Online human interaction and interaction with digital resources" established at the International Summit on ICT in Education in 2019. The TWG7 defined connected learning as leveraging "media and technology for expanded access to global communities and cross-cultural and interdisciplinary learning pathways across the lifespan" (International Summit on ICT in Education 2019).

The role of networked learning with the support of convivial technologies is discussed. Convivial tools afford networks of people (with common ground or interests) the opportunity to connect regardless of the format of the medium (i.e., virtual or inperson networks). In this paper, it is argued that social media represents a convivial technology in which individuals are engaging in networked learning. Additionally, this paper provides a review of educational reforms in Latin America. It also shares an overview of the current state of ICT integration in different educational levels.

The core of this paper focuses on some of the current informal, non-formal and formal networked learning initiatives taking place in Latin America. These include the use of institutional social media, educational hashtags, social media in the classroom (virtual and in-person), educational channels via video hosting platforms, and government established networked learning programs for connected classrooms. The same multiplicity, diversity, and heterogenicity that represent the culture, languages, and socioeconomic status of the people of Latin America can also characterize the vast mixture of networked learning initiatives across the region.

To aid those considering networked learning initiatives in Latin America, policymakers, and education leaders, this paper provides potential barriers (i.e., the digital divide, Internet filtering policies, lack of research) and opportunities (i.e., networked learning educational reforms, mobile learning technology, the teaching ethical and critical considerations) for implementation. This paper concludes with recommendations that policymakers and education leaders in Latin America should keep in mind in order to engage in fruitful networked learning initiatives.

\section{Compliance with ethical standards}

Conflict of interest The author declares that she has no conflict of interest. 


\section{References}

Amadio, M. (2009). Inclusive education in Latin America and the Caribbean: Exploratory analysis of the national reports presented at the 2008 International Conference on Education. Prospects, 39(3), 293-305. https://doi.org/10.1007/s11125-009-9114-1.

Annisette, L. E., \& Lafreniere, K. D. (2017). Social media, texting, and personality: A test of the shallowing hypothesis. Personality and Individual Differences, 115, 154-158. https://doi.org/10.1016/j. paid.2016.02.043.

Albion, P., Knezek, D., \& Adubra, E. (2011). TWG3: Teacher professional development. EDUsummIT 2011. Paris: UNESCO.

Alderete, M. V. (2019). Broadband adoption in Latin American countries: Does geographic proximity matter? Problemas del Desarrollo. https://doi.org/10.22201/iiec.20078951e.2019.198.67411.

Alzain, H. A. (2019). The role of social networks in supporting collaborative e-learning based on connectivism theory among students of PNU. Turkish Online Journal of Distance Education (TOJDE), 20(2), 46-63.

Arnett, A. A. (2015). Color struck. Diverse: Issues in Higher Education, 32(17), 14-17.

Aydin, S. (2012). A review of research on Facebook as an educational environment. Educational Technology Research and Development, 60(6), 1093-1106. https://doi.org/10.1007/s11423-012-9260-7.

Ballesteros Ballesteros, V. A., Iván Rodríguez-Cardoso, Ó., Lozano-Forero, S., \& Luis NisperuzaToledo, J. (2020). El Aprendizaje Móvil en Educación Superior: Una Experiencia desde la Formación de Ingenieros. Revista Científica, 38(2), 1-21. https://doi.org/10.14483/23448350.15214.

Benítez Larghi, S. (2020). Desafíos de la inclusión digital en Argentina. Una mirada sobre el Programa Conectar Igualdad. Revista de Ciencias Sociales, 33(46), 131-154. https://doi.org/10.26489/rvs. v33i46.7.

Bernasconi, A., \& Celis, S. (2017). Higher education reforms: latin america in comparative perspective. Reformas de la educación superior: América Latina en perspectiva comparada, 25(67/73), 1-15. https://doi.org/10.14507/epaa.25.3240.

Bishop, A. P., Bazzell, I., Mehra, B., \& Smith, C. (2001). Afya: Social and digital technologies that reach across the digital divide. First Monday. https://doi.org/10.5210/fm.v6i4.847.

Blasco, M., \& Krause Hansen, H. (2006). Cosmopolitan aspirations: New media, citizenship education and youth in Latin America. Citizenship Studies, 10(4), 469-488. https://doi.org/10.1080/13621 020600857890.

Butler, D., Leahy, M., Twining, P., Akoh, B., Chtouki, Y., Farshadnia, S., et al. (2018). Education systems in the digital age: The need for alignment. Technology, Knowledge and Learning, 23, 473494. https://doi.org/10.1007/s10758-018-9388-6.

Cabero, J., \& Marin, V. (2013). Latin American university students' perceptions of social networks and group work. Universities and Knowledge Society Journal (RUSC), 10(2), 462-477. https://doi. org/10.7238/rusc.v10i2.1728.

Carpenter, J., \& Krutka, D. (2014). How and why educators use Twitter: A survey of the field. Journal of Research on Technology in Education, 46, 414-434. https://doi.org/10.1080/15391523.2014.92570 1.

Carpenter, J., Tani, T., Morrison, S., \& Keane, J. (2020). Exploring the landscape of educator professional activity on Twitter: An analysis of 16 education-related Twitter hashtags. Professional Development in Education. https://doi.org/10.1080/19415257.2020.1752287.

Carvalho, L. (2018). Networked societies for learning: Emergent learning activity in connected and participatory meshworks. In M. J. Spector, B. B. Lockee, \& M. D. Childress (Eds.), Learning, design, and technology: An international compendium of theory, research, practice, and policy (pp. 1-22). Cham: Springer.

Centro de Inovacion. (2019). Aulas Conectadas. Retrieved April 17, 2020, from http://innovacion.mined uc.cl/aulas-conectadas-2019/.

Chen, B., \& Bryer, T. (2012). Investigating instructional strategies for using social media in formal and informal learning. International Review of Research in Open and Distance Learning, 13(1), 87-104. https://doi.org/10.19173/irrodl.v13i1.1027.

Cobo, C., Hawkins, R., \& Rovner, H. (2020). How countries across Latin America use technology during COVID19-driven school closures. Washington, DC: World Bank Group.

Constantinides, E., \& Zinck Stagno, M. C. (2011). Potential of the social media as instruments of higher education marketing: A segmentation study. Journal of Marketing for Higher Education, 21(1), 7-24. https://doi.org/10.1080/08841241.2011.573593.

Davis, T. (2013). Building and usicng a persona/professional learning network with social media. Journal of Research in Business Education, 55(1), 1-13. 
Deibert, R., Palfrey, J., Rohozinski, R., \& Zittrain, J. (2008). Access denied: The practice and policy of global internet filtering. Cambridge, MA: MIT Press.

Dennen, V. P., \& Burner, K. J. (2017). Identity, context collapse, and Facebook use in higher education: Putting presence and privacy at odds. Distance Education, 38(2), 173-192. https://doi.org/10.1080/01587 919.2017.1322453.

Dennen, V. P., Choi, H., \& Word, K. (2020). Social media, teenagers, and the school context: A scoping review of research in education and related fields. Educational Technology Research and Development, 68(4), 1635-1658.

Ding, H. (2020). Crowdsourcing, social media, and intercultural communication about Zika: Use contextualized research to bridge the digital divide in global health intervention. Journal of Technical Writing and Communication, 50(2), 141-166. https://doi.org/10.1177/0047281620906127.

Duque, A. P. G., \& del Moral Pérez, M. E. (2013). Twitter's contribution to improving strategic communication in Latin American universities. Contribución de Twitter a la mejora de la comunicación estratégica de las universidades latinoamericanas, 10(2), 478-493. https://doi.org/10.7238/rusc.v10i2 1744 .

Eckberg, D. A., Densley, J., \& Dexter, K. (2018). When legend becomes fact, Tweet the legend: Information and misinformation in the age of Social Media. Journal of Behavioral and Social Sciences, 5(3), $148-156$.

Fainholc, B. (2016). Presente y futuro latinoamericano de la enseñanza y el aprendizaje en entornos virtuales referidos a educacion universitaria. Revista de Educatión a Distancia. https://doi.org/10.6018/ $\mathrm{red} / 48 / 2$.

Gadotti, M. (2011). Adult education as a human right: The Latin American context and the ecopedagogic perspective. International Review of Education/Internationale Zeitschrift für Erziehungswissenschaft, 57(1/2), 9-25. https://doi.org/10.1007/s11159-011-9205-0.

Gao, F., Luo, T., \& Zhang, K. (2012). Tweeting for learning: A critical analysis of research on microblogging in education published in 2008-2011. British Journal of Educational Technology, 43(5), 783801. https://doi.org/10.1111/j.1467-8535.2012.01357.x.

Gainous, J., Wagner, K., \& Gray, T. (2016). Internet freedom and social media effects: Democracy and citizen attitudes in Latin America. Online Information Review, 40(5), 712-738. https://doi.org/10.1108/ OIR-11-2015-0351.

Gebera, O. W. T. (2010). Contexto y desarrolo de la modalidad educativa blended learning en el sistema universitario Iberoamericano. Revista Mexicana de Investigación Educativa, 15(45), 345-370.

Gonzalez, C., \& Muñoz, L. (2016). Redes sociales su impacto en la educationa superior: Caso de studio University Tecnologica de Panama. Campus Virtuales, 5(1), 84-90.

Greenhalgh, S., \& Koehler, M. (2017). 28 days later: Twitter hashtags as 'just in time' teacher professional development. TechTrends: Linking Research and Practice to Improve Learning, 61(3), 273-281. https ://doi.org/10.1007/s11528-016-0142-4.

Greenhow, C., \& Lewin, C. (2016). Social media and education: Reconceptualizing the boundaries of formal and informal learning. Learning, Media and Technology, 41(1), 6-30. https://doi.org/10.1080/17439 884.2015.1064954.

International Summit on ICT in Education. (2019). EDUsummIT2019: Learners and learning contexts: New alignments for the digital age. Retrieved April 17, 2020, from https://edusummit2019.fse.ulaval.ca/ index.html.

Jara, I., Claro, M., \& West, M. (2012). Mobile learning for teachers in Latin America: Exploring the potential of mobile technologies to support teachers and improve practice (white paper). Paris: United Nations Educational, Scientific and Cultural Organization (UNESCO).

Juric, P., Bakaric, M. B., \& Matetic, M. (2018). Design and implementation of anonymized social networkbased mobile game system for learning mathematics. International Journal of Emerging Technologies in Learning, 13(12), 83-98. https://doi.org/10.3991/ijet.v13i12.8762.

Kearney, M., \& Maher, D. (2019). Mobile learning in pre-service teacher education: Examining the use of professional learning networks. Australasian Journal of Educational Technology, 35(1), 135-148. https://doi.org/10.14742/ajet.4073.

Kennedy, J. (2018). Towards a model of connectedness in personal learning networks. Journal of Interactive Online Learning, 16(1), 21-40.

Kim, P., Miranda, T., \& Olaciregui, C. (2008). Pocket School: Exploring mobile technology as a sustainable literacy education option for underserved indigenous children in Latin America. International Journal of Educational Development, 28(4), 435-445. https://doi.org/10.1016/j.ijedudev.2007.11.002.

Kimmons, R., Veletsianos, G., \& Woodward, S. (2016). Institutional uses of Twitter in U.S. higher education. Innovative Higher Education. https://doi.org/10.1007/s10755-016-9375-6. 
Krutka, D. G., \& Damico, N. (2020). Should we ask students to tweet? Perceptions, patterns, and problems of assigned social media participation. Contemporary Issues in Technology and Teacher Education, 20(1), 142-175.

Krutka, D. G., Heath, M. K., \& Mason, L. E. (2020). Editorial: Technology won't save us: A call for technoskepticism in social studies. Contemporary Issues in Technology and Teacher Education, 20(1), 108-120.

Krutka, D. G., Manca, S., Galvin, S., Greenhow, C., Koehler, M., \& Askari, E. (2019). Teaching "against" social media: Confronting of profit in the curriculum. Teachers College Record, 121(14), $1-19$.

Lugo, M. T., \& Schurmann, S. (2012). Turning on mobile learning in Latin America: Illustrative initiatives and policy implications (white paper). Paris: United Nations Educational, Scientific and Cultural Organization (UNESCO).

Luo, T., Freeman, C., \& Stefaniak, J. (2020). "Like, comment, and share": Professional development through social media in higher education: A systemic review. Educational Technology Research and Development, 68(4), 1659-1683.

Manca, S., \& Ranieri, M. (2017). Implications of social network sites for teaching and learning. Where we are and where we want to go. Education and Information Technologies, 22(2), 605-622. https:// doi.org/10.1007/s10639-015-9429-X.

Mayayo, J. L., Romaní, J. R., \& Duran, R. Q. (2020). Management and leadership of networks for educational success: Analysis of emerging networks in Spain. School Leadership and Management, 40(2-3), 183-202. https://doi.org/10.1080/13632434.2019.1692197.

Networked Learning Editorial Collective. (2020). Networked learning: Inviting redefinition. Postdigital Science Education. https://doi.org/10.1007/s42438-020-00167-8.

Ontiveros, M., de la Barquera, S., \& Pazos, J. R. C. (2013). Education and technology in Mexico and Latin America: Outlook and challenges introduction. Knowledge Spaces Educación y tecnología en México y América Latina Perspectivas y retos, 10(2), 407-413. https://doi.org/10.7238/rusc.v10i2.1848.

Organisation for Economic Co-operation and Development (OECD). (2005). The role of the national qualifications system in promoting lifelong learning: Report from thematic group 2: Standards and quality assurance in qualifications with special reference to the recognition of non-formal and informal learning (p. 5). Paris: Organisation for Economic Co-operation and Development (OECD).

Rehm, M., \& Notten, A. (2016). Twitter as an informal learning space for teachers!? The role of social capital in Twitter conversations among teachers. Teaching and Teacher Education, 60, 215-223. https://doi.org/10.1016/j.tate.2016.08.015.

Rodriguez, H., \& Restrepo, L. F. (2015). Conocimientos y uso del Twitter por parte de estudiantes de education superior. Sophia, 11(1), 44-52.

Rodríguez, L. M. (2009). La educación de adultos en la historia reciente de América Latina y el Caribe. Moreno Martínez, P.L. y Navarro García, C. (Coords.) Perspectivas históricas de la educación de personas adultas. 3, No 1. Universidad de Salamanca. [Fecha de consulta] Retrieved from http:// www.usal.es/efora/efora_03/articulos_efora_03/n3_01_rodriguez.pdf. Accessed 29 April 2014.

Romero-Hall, E. (2017a). Posting, sharing, networking, and connecting: Use of social media content by graduate students. TechTrends, 61(6), 580-588. https://doi.org/10.1007/s11528-017-0173-5.

Romero-Hall, E. (2017b). Active user or lurker? A phenomenological investigation of graduate students in social media spaces. International Journal of Social Media and Interactive Learning Environments, 5(4), 326-340. https://doi.org/10.1504/IJSMILE.2017.10012109.

Romero-Hall, E., Kimmons, R., \& Veletsianos, G. (2018). Social media use by instructional design department. Australasian Journal of Educational Technology, 34(5). https://doi.org/10.14742/ajet.3817.

Romero-Hall, E., Petersen, E., Sindicic, R., \& Li, L. (2020). Most versus least used social media: Undergraduate students' preferences, participation, lurking, and motivational factors. International Journal of Social Media and Interactive Learning Environments, 6(3), 244-266. https://doi.org/10.1504/ IJSMILE.2020.109266.

Rosenberg, J. M., Terry, C. A., Bell, J., Hiltz, V., \& Russo, T. (2016). Design guidelines for graduate program social media use. TechTrends, 60(2), 167-175. https://doi.org/10.1007/s11528-016-0023-X.

Social Media Fact Sheet. (2019). Demographics of social media users and adoptions in the United States. Washington, DC: Pew Research Center.

Staudt Willet, K. B. (2019). Revisiting how and why educators use Twitter: Tweet types and purposes in \#Edchat. Journal of Research on Technology in Education, 51(3), 273-289. https://doi. org/10.1080/15391523.2019.1611507.

Sucre, F. \& Manning, A. (2016). The potential of mobile learning in Latin America. The dialogue: leadership for the Americas. Retrieved April 17, 2020, from https://www.thedialogue.org/blogs /2016/08/the-potential-of-mobile-learning-in-latin-america/. 
Trust, T., \& Prestridge, S. (2021). The interplay of five elements of influence on educators' PLN actions. Teacher and Teacher Education. https://doi.org/10.1016/j.tate.2020.103195.

Twining, P., Raffaghelli, J., Albion, P., \& Knezek, D. (2013). Moving education into the digital age. Journal of Computer Assisted Learning, 29, 426-437. https://doi.org/10.1111/jcal.12031.

Valencia-Arias, A., Benjumea Arias, M. L., Morales Zapata, D., Silva Cortes, A., \& Betancur Zuluaga, P. (2018). Actitudes de docentes universitarios frente al uso de dispositivos móviles con fines académicos. Revista Mexicana de Investigación Educativa, 23(78), 761-790.

Veletsianos, G. (2016). Social media in academia. New York, NY: Routledge.

Veletsianos, G., Kimmons, R., Shaw, A., Pasquini, L., \& Woodward, S. (2017). Selective openness, branding, broadcasting, and promotion: Twitter use in Canada's public universities. Educational Media International, 54(1), 1-19. https://doi.org/10.1080/09523987.2017.1324363.

Werquin, P. (2007). Moving mountains: Will qualifications systems promote lifelong learning? European Journal of Education, 42(4), 459-484. https://doi.org/10.1111/j.1465-3435.2007.00327.x.

Whaite, E. O., Shensa, A., Sidani, J. E., Colditz, J. B., \& Primack, B. A. (2018). Social media use, personality characteristics, and social isolation among young adults in the United States. Personality and Individual Differences, 124, 45-50. https://doi.org/10.1016/j.paid.2017.10.030.

Yuni, J. A., Meléndez, C. E., \& Díaz, A. G. (2014). Equidad y políticas universitarias: perspectivas desde latinoamerica. REDU: Revista de Docencia Universitaria, Número monográfico dedicado a Equidad y Calidad en la Docencia Universitaria: Perspectivas Internacionales, 12(2), 41-60.

Publisher's Note Springer Nature remains neutral with regard to jurisdictional claims in published maps and institutional affiliations.

Enilda Romero-Hall is an Associate Professor in the Department of Education at The University of Tampa. She is also the Graduate Coordinator of the Instructional Design and Technology program. Dr. RomeroHall is particularly interested in the design and development of interactive multimedia, faculty and learners' digital literacy and preparedness, and networked learning in online social communities. Other research areas include innovative research methods in learning design and technology; culture, technology, and education; and feminist pedagogies. More can be found on her website: https://www.enildaromero.net. 